\section{Ecosystem-based climate change adaptation for Essenvelt, Middelburg, The Netherlands}

\author{
Wim Timmermans, Cor Jacobs, Tim van Hattum, Louis Lategan \\ \& Juaneé Cilliers
}

http://dx.doi.org/10.18820/2415-0495/trp71i1.3

Peer reviewed and revised October 2017

\begin{abstract}
Climate change is an internationally recognised phenomenon generally held accountable for the increasing magnitude of extremes in both climatic events and temperature. With increasing urbanization and the concentration of socio-economic activities in urban areas, the challenge to contend with climate change is particularly pertinent in cities. In response to climate-change impacts, a range of climateadaptation strategies have been developed to make cities increasingly "climate proof'. A qualitative research approach is employed to review climate change, its impacts and some adaptation strategies, focusing on ecosystem-based adaptation strategies from Belgium and The Netherlands and Water-Sensitive Urban Design approaches developed in Australia. The article engages a case study of Essenvelt, Middelburg, The Netherlands, where unanticipated warmer night-time temperatures are a primary concern, related to natural variability, the urban heat island effect and climate change. The article proposes certain adaptation measures for Essenvelt, based on the adaptation strategies reviewed.
\end{abstract}

Keywords: Adaptation, climate change, ecosystem-based, water-sensitive urban design, WSUD

\section{'N OORWEGING VAN KLIMAATSVERANDERING: EKOSISTEEMGEBASEERDE AANPASSING EN WATERSENSITIEWE STEDELIKE ONTWERPAANBEVELINGS VIR ESSENVELT, MIDDELBURG, NEDERLAND}

Klimaatsverandering is ' $n$ verskynsel wat internasionale erkenning geniet en algemeen aanspreeklik gehou word vir die toenemende omvang van uiterste klimaatstoestande en gebeure. Met verstedeliking wat toeneem en die konsentrasie van sosio-ekonomiese aktiwiteite in stedelike gebiede, word stede veral geraak deur die uitdaging om klimaatsverandering aan te spreek. In reaksie tot die impak van klimaatsverandering is ' $n$ verskeidenheid klimaataanpassingstrategieë ontwikkel om stede meer 'klimaatbestand' te maak. 'n Kwalitatiewe navorsingsbenadering word gevolg om klimaatsverandering, impakte en sekere aanpassingstrategieë te ondersoek met 'n fokus op ekosisteemgebaseerde aanpassingstrategieë uit België en Nederland, en Water-Sensitiewe Stedelike Ontwerp uit Australië. Die artikel betrek 'n gevallestudie van Essenvelt, Middelburg, Nederland, waar onverwagte warmer nagtemperature, in verband met natuurlike veranderlikheid, die stedelike hitte eilandeffek en klimaatsverandering, geïdentifiseer word. Die artikel stel sekere klimaataanpassingstrategieë voor vir Essenvelt, gebaseer op die aanpassingstrategieë wat bespreek is.

Sleutelwoorde: Aanpassing, ekosisteemgebaseer, klimaatsverandering, WaterSensitiewe Stedelike Ontwerp, WSUD

\section{Tlwaelo bakeng sa phetoho ya boemo ba lehodimo e itshetlehileng hodima tikoloho mabapi le Essenvelt, Middelburg, Netherlands}

Phetoho ya boemo ba lehodimo ke ketsahalo e tsejwang ke matjhaba, eo ka kakaretso e nkilweng e ikarabella bakeng sa boholo bo eketsehileng ba diketsahalo tse fetelletseng tsa phetoho ya boemo ba lehodimo le ho motjheso o fetelletseng. Ka lebaka la ho eketseha ha ditoropo le tsepamiso ya maikutlo ho diketsahalo moruong wa setjhaba ditoropong, phepetso ya ho sokola ka phetoho ya boemo ba lehodimo e tlwaelehile ditoropong. Bakeng sa ho arabela ho ditshusumetso tsa phetoho ya boemo ba lehodimo, ho hlahisitswe maano a ho itlwaetsa a itseng; ho etsa hore ditoropo di dule di sirelletsehile phetohong ya boemo ba lehodimo. Mokgwa wa diphuputso tsa boleng o sebediswa ho lekodisisa phetoho ya boemo ba lehodimo, ditshusumetso tsa yona le maano a ho itlwaetsa a itseng a tsepamisang maikutlo hodima maano a boitlwaetso a itshetlehileng hodima tikoloho; a tswang Belgium, Netherlands le ho mekgwa ya moralo wa setoropong wa thokomelo ya metsi e tswang Australia. Atikele ena e kenyelletsa thuto ya mehlala ya Essenvelt, Middelburg le Netherlands moo teng motjheso o eketsehileng nakong tsa bosiu, e leng kgathatso e ka sehloohong e amanang le diphapang tsa tholeho, tshusumetso ya urban heat island le phetoho ya boemo ba lehodimo. Atikele ena e sisinya/hlahisa mekgwa ya ho itlwaetsa e itseng bakeng sa Essenvelt, e itshetlehileng hodima maano a boitlwaetso a hlahlobilweng.

Mantswe a sehlooho: Boitlwaetso, phetoho ya boemo ba lehodimo, se itshetlehileng tikolohong, Moralo wa motse setoropo wa thokomelo ya metsi, WSUD

\section{INTRODUCTION}

Climate change may result in environmental changes that extend beyond existing and historical natural variability (Gibbs, 2015: 207). There is a growing recognition of

Dr. Wim Timmermans, Researcher Climate adaptation, Wageningen Environmental Research Team Climate Change, Post Box 47 6700AA, Wageningen. Netherlands. Phone: +31 (0)317486405, email: <wim.timmermans@wur.nl>

Dr. Cor Jacobs, Researcher on micrometeorology and gas exchange, Wageningen Environmental Research Team Climate Change, Post Box 47 6700AA Wageningen. Netherlands. Phone: +31 (0)317486460, email: <cor.jacobs@wur.nl>

T. van Hattum, Researcher Climate change, Wageningen Environmental Research Team Climate Change, Post Box 47, 6700AA Wageningen, Netherlands. Phone: +31 (0)317483441, email: <tim.vanhattum@wur.nl>

Dr. Louis (L.G.) Lategan, Unit for Environmental Sciences and Management, North-West University, Private Bag X6001, Potchefstroom, 2520. Phone: 018299 2486, email: <latlou.info@gmail.com>

Prof. Juaneé (EJ) Cilliers, Urban and Regional Planning, School for Geo and Spatial Sciences, Potchefstroom Campus, North-West University, Private Bag X6001, Potchefstroom, 2520, South Africa. Phone: 083414 3939, email: <juanee.cilliers@nwu.ac.za> 
global climate change, including an increasing cognisance of extreme climatic events with more intense storms, longer droughts (Muller, 2007: 103), and extreme temperatures. The resultant enhanced risks expressed at local level include threats to human health and safety, property, agriculture, infrastructure, services, and the local environment (Fussel, 2008: 45; Kennedy, Stocker \& Burke, 2010: 805; Claes, Vandenbussche, Versele, Klein \& Verbist, 2012: 15; Bizikova, Crawford, Nijniik \& Swart, 2014: 412; Ziervogel, Midgley, Myers, New, Taylor, Van Garderen, Hamann, Warburton \& Stuart-Hill, 2014: 606; IPCC, 2014: 6; Gibbs, 2015: 207; Hu, Hall, Shi \& Lim, 2016: 1083; EEA, 2017: 105-310). With increasing urbanization and an ongoing concentration of socioeconomic activities in urban areas, the challenge to cope with climate change is particularly pertinent in cities (EEA, 2012: 6).

This article focuses on climate adaptation strategies in cities. It is important to review climate change impacts with examples of related disasters to underscore the urgency for climate adaptation strategies. By discussing basic concepts related to climate adaptation, three categories of adaptation strategies can be identified, from which planning and management instruments can be selected; this article focuses on ecosystem-based adaptation approaches. Accordingly, ecosystembased adaptation strategies from Belgium and The Netherlands and the Water-Sensitive Urban Design (WSUD) approach pioneered in Australia have been summarised to exemplify how adaptation strategies may be formulated and implemented. A case study of Essenvelt, Middelburg, The Netherlands, where unexpected warmer night-time temperatures are a result of natural variability, in all probability intensified by the urban heat island effect and climate change, was used to apply the adaptation proposals discussed, in order to recommend certain adaptation strategies for Essenvelt utilising wind, building design, and blue-green infrastructure possibilities.
The case study was examined following a desktop analysis on the basis of ongoing research on temperature variations and climatic conditions in Middelburg.

\section{CLIMATE CHANGE}

\subsection{Climate change impacts}

Europe will undergo significant hydro-climatic changes in the future, with the north predicted to become wetter (Gudmundsson \& Seneviratne, 2016: 1-6) as yearly precipitation increases as a result of climate change (EEA, 2017: 12). Heavy rainfalls, cloudbursts and resulting floods have already and will increasingly wreak havoc across much of Europe (Van Hattum, Blaauw, Bergen Jensen \& De Bruin, 2016: 4), placing people and infrastructure in crisis (EEA, 2017: 12). Examples include flooding across Europe in August 2002, causing 232 fatalities and billions of euros in damage (Kundzewicz, 2015: 189); downpours in 2011 , amounting to over $120 \mathrm{~mm}$ of rainfall, causing floods in Copenhagen, Denmark, resulting in more than one billion euros in damage, and extreme rainfall and hail in The Netherlands' south-eastern region in 2016 , causing damage amounting to over 550 million euros.

\section{Gudmundsson \& Seneviratne} (2016: 1) provide evidence that, although drought is a significant natural hazard in Europe, affecting $37 \%$ of the European Union over the past decade, southern Europe presents an increased risk of drought, whilst the probability of dry years has decreased in the north. Droughts may cause water shortfalls, famines, natural fires, degraded soil and water quality, as well as increased health risks to the population (Samaniego, Thober, Kumar, Rakovec, Wood, Sheffield, Pan, Wanders \& Prudhomme, 2017: 1). Drought and temperatures spikes are often interconnected. Heat waves may have significant consequences. Europe has suffered from several heatwaves, among which the infamous European heatwave in the summer of 2003 that claimed an additional 70,000 lives, with a great number of victims residing in urban areas (Robine, Cheung, Leroy, Vanoyen, Griffiths, Michel \& Herrmann, 2008: 171). According to a recent analysis, heat extremes caused over $90 \%$ of the casualties related to extreme weather events between 1991 and 2015 (EEA, 2017: 203).

The Netherlands is located in north-western Europe and belongs to a group of countries and regions with a marine West coast climate (Köppen-Geiger classification $\mathrm{Cfb}$ ). The annual average rainfall amounts to $851 \mathrm{~mm}$ (reference period 1981-2010). Since average annual evaporation is estimated at $561 \mathrm{~mm}$, this results in a surplus of precipitation on an annual basis. However, strong seasonal variations may lead to dry spells during the summer season, in particular, and an average maximum precipitation deficit in the growing season (AprilSeptember) of $140 \mathrm{~mm}$ (Noordhof Atlasproducties/KNMI, 2011). Whereas climate change is expected to result in more extreme precipitation events, in particular in the strongly urbanised coastal areas, more extended periods of drought may also be expected (Van Den Hurk, Siegmund \& Klein Tank, 2014). While the average annual rainfall may increase by up to $6 \%$, summer precipitation may increase slightly by $1 \%-2 \%$ or decrease strongly by $11 \%-13 \%$ in 2050 , depending on possible changes in large-scale circulation patterns and the global temperature increase. With an expected increase in evaporation of up to $11 \%$ in summer, this could lead to an increase in growingseason precipitation deficits of up to $30 \%$. Along with an expected rise in sea levels $(1.0 \mathrm{~mm}-7.5 \mathrm{~mm}$ per year), this may result in problematic salt intrusion in coastal areas (Klimaat, 2017: online).

The average annual temperature (reference period 1981-2010) varies from about $10.5^{\circ} \mathrm{C}$ in the south-west to about $9.5^{\circ} \mathrm{C}$ in the north-east. The two warmest months are July and August, with average maximum temperatures of about $23^{\circ} \mathrm{C}$ and minima of around $13^{\circ} \mathrm{C}$. Days with 
maximum temperatures exceeding $25^{\circ}$ (so-called 'summer days') typically occur from 10 to 20 times in most of the coastal areas to 30 to 40 times per year in more inland parts in the south-east (Noordhof Atlasproducties/KNMI, 2011). According to recent climate scenarios generated by the Royal Netherlands Meteorological Institute, average annual and summer season temperatures may have increased by $1.0 \%-2.3^{\circ} \mathrm{C}$ in 2050 , again depending on possible changes in large-scale circulation patterns and the global temperature increase (Van den Hurk et al., 2014). Moreover, the number of 'summer days' may increase by $22 \%-70 \%$.

Given the generally mild conditions experienced in The Netherlands, the problem of heat stress has long been ignored. However, heat-related casualties during the heatwaves of 2003 and 2006 have underlined the issue more (Van Hove, Steeneveld, Jacobs, Ter Maat, Heusinkveld, Elbers, Moors \& Holtslag, 2010). Increased recognition is warranted, as temperature extremes are likely to be affected more than the average, leading to more intense heatwaves (Van Den Hurk et al., 2014) and, therefore, more casualties in the future. Figure 1 (adapted from Huynen, Maartens, Schram, Weijenberg \& Kunst, 2001: 463) illustrates the relationship between average daily temperature and mortality. The figure shows the ratio of the observed number of deaths and the long-term average number of deaths on a particular day versus observed temperature. It can be noted that a minimum in the number of casualties occurs at about $16.5^{\circ} \mathrm{C}$ and that both cold and hot conditions lead to enhanced mortality. The curve predicts that a typical heatwave in The Netherlands could cause 40 additional deaths daily. On average, the higher number of heat-related deaths in a warmer future climate will not be balanced by a lower number of cold-related casualties (Rovers, Bosch \& Albers, 2015: 37).

Urbanization may exacerbate these numbers in Dutch cities. Figure 2 schematically illustrates the effect of a possible combination

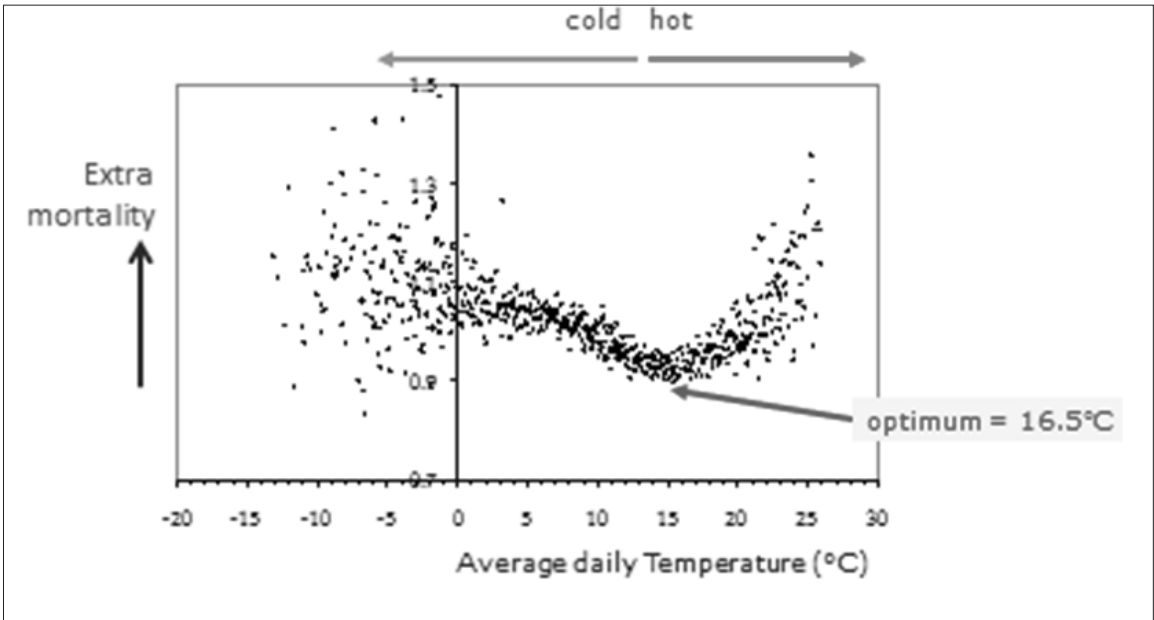

Figure 1: Relation between temperature and excess mortality. See main text for further explanation. After Huynen et al., 2001.

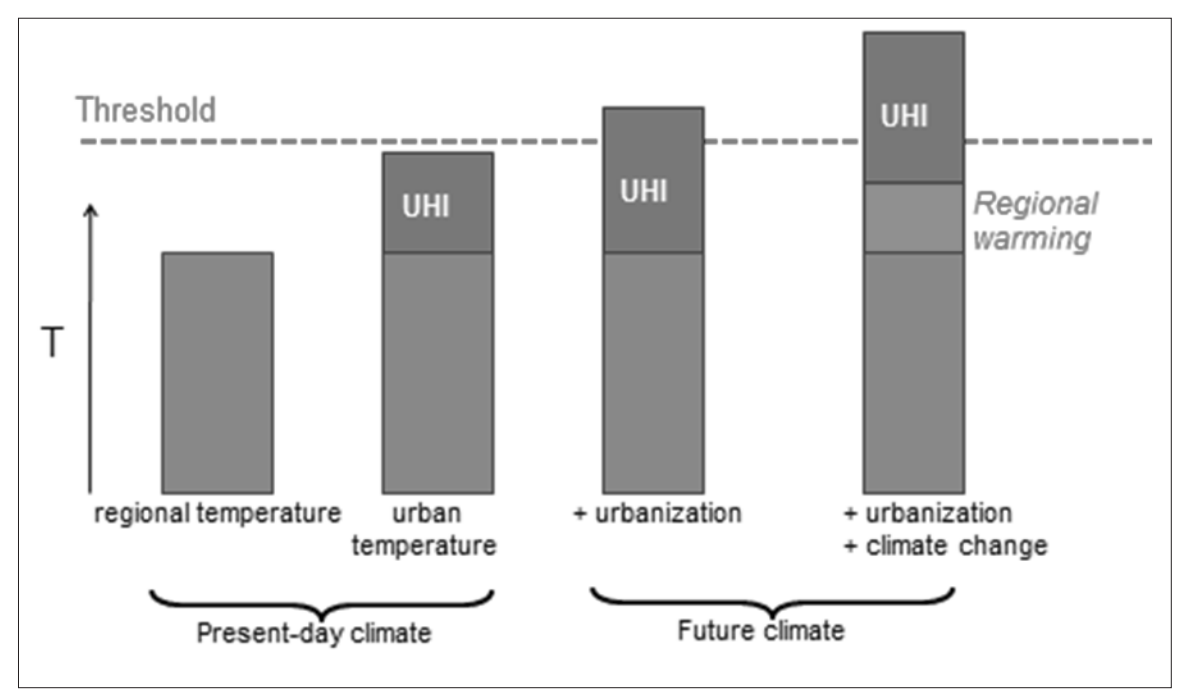

Figure 2: Influence of climate change and urbanisation on heat stress. Urbanisation affects the urban heat island (UHI). See main text for further explanation. Figure design: Bert van Hove, Wageningen University

of regional climate change and urbanization. The column on the left shows the present-day situation in rural areas. Research has shown that critical heat thresholds are at present approached in both large and small cities and villages in The Netherlands, partly due to the urban heat island effect (Steeneveld, Koopmans, Heusinkveld, Van Hove \& Holtslag, 2011). This is illustrated in the second column of Figure 2. The third and fourth columns, respectively, show how urbanization leads to increased urban heat island intensity, which may result in exceedance of the critical threshold along with the aforementioned regional climate change. The urban heat island effect is known to be a night-time phenomenon, leading to higher minimum temperatures in cities (Oke, 1981; Fang, 2015: 2195; Milojevic, Armstrong, Gasparrini, Bohnenstengel, Barratt \& Wilkinson, 2016: 1016). This is important due to the aforementioned sensitivity of human beings to night-time temperature. The number of so-called tropical nights (minimum temperature over $20^{\circ} \mathrm{C}$ ) presently averages about 5 per year in the centre of larger cities in The Netherlands, but may increase to several tens per year around 2050 (Klimaat, 2017), partly related to the urban heat island. It is important to note that regional climate change is, to a large extent, driven by global change, but that, in principle, local planning measures can reduce urban heat island intensity.

Whereas the immediate effects of storms and floods may be more 
obvious, droughts and heatwaves can also have other significant impacts beyond loss of life in several sectors (for a comprehensive discussion on impacts of extreme heat in cities, see Klok \& Kluck, 2017). A wellknown example is demonstrated by a decrease in productivity: a temperature rise of about two degrees may halve productivity, once a critical value has been exceeded (Smith, Woodward, Campbell-Lendrum, Chadee, Honda, Liu, Olwoch, Revich \& Sauerborn, 2014: 732). An initial analysis of The Netherlands indicates that loss of productivity would constitute the bulk of additional cost levied by global warming, given the impacts of reduced thermal comfort and increased heat stress, further exacerbated by the urban heat island effect (Daanen, Jonkhoff, Bosch \& ten Broeke, 2013: 16). The impacts of climate change are expected to increase the occurrence of naturally occurring heatwaves and droughts. Combined with the urban heat island effect and more intense urbanization, this may, in the future, lead to critical values being exceeded more often (see Figure 2).

\subsection{Climate adaptation}

The severe consequences of climate change have resulted in more arduous discussions on climate adaptation in policy and practice (Kennedy et al., 2010: 805), following fairly weak past attempts at mitigation to reduce climate change impacts (Laukkonen, Blanco, Lenhart, Keiner, Cavric \& Kinuthia-Njenga, 2009: 288; Gibbs, 2015: 206). In 2014, the International Panel on Climate Change (IPCC) defined adaptation as:

\begin{abstract}
The process of adjustment to actual or expected climate and its effects. In human systems, adaptation seeks to moderate or avoid harm or exploit beneficial opportunities. In some natural systems, human intervention may facilitate adjustment to expected climate and its effects...in natural or human systems in response to actual or expected climatic stimuli or their effects, which moderates harm or exploits beneficial opportunities (IPCC, 2014: 118).
\end{abstract}

Fussel (2008: 37) contends that such adjustments are usually the result of 'action by individuals, social groups, or institutions'. As the adaptation agenda has gained momentum, cities and communities have developed their own intervention strategies to address climate change adaptation (Bulkeley \& Tuts, 2013: 647). Whereas most human societies are inherently adaptive, climate change may test coping capacities to their limits (Muller, 2007: 102) and may demand increasingly creative planning, development and management solutions. As such, climate change intervention frameworks are being developed at a rapid pace worldwide, increasingly providing opportunities for multi-level and transnational communication that allows local authorities to draw from international experience and new developments (Bulkeley \& Tuts, 2013: 657). Whereas it is important to recognise and learn from international 'best practice', individual place-based responses (Wamsler, Niven, Beery, Bramryd, Ekelund, Jönsson, Adelina Osmani, Palo \& Stålhammar, 2016: 1) at local level are crucial. Climate change impacts are expressed particularly in specific regions and places and on specific communities and ecosystems (Kennedy et al., 2010: 805) that present a myriad of unique pressures that influence the ability to respond to climate vulnerability and adaptation. A 'one-size-fits-all' approach will likely be unsuccessful (Bulkeley \& Tuts, 2013: 650).

In considering existing approaches, urban planning, through land-use planning, spatial strategies and water management, provides a range of instruments capable of addressing climate change through long-term development decisions that may incorporate disaster preparedness and response efforts (EEA, 2012: 76; Bulkeley \& Tuts, 2013: 658). Climate adaptation planning and management instruments are typified by hard and soft approaches (Muller, 2007: 102). Hard approaches refer to engineered structures such as flood walls, dykes and polders, whereas soft approaches encompass issues such as raising awareness and institutional capacity-building. Green-based, ecosystem-oriented adaptation, defined as "the use of biodiversity and ecosystem services as part of an overall adaptation strategy" (CBD 2009: 41), is included either under soft approaches or may represent a third approach altogether (Wamsler et al., 2016: 3).

Ecosystem-based adaptations are becoming more commonplace, gradually evolving to replace a previous focus on green infrastructure (Colding, 2007: 50; Tzoulas, Korpela, Venn, Yli-Pelkonen, Kazmierczak, Niemele \& James, 2007: 170; Cilliers, Diemont, Stobbelaar \& Timmermans, 2011: 583; Biotope-city, 2017) to embrace approaches that combine blue-green infrastructure (Wamsler et al., 2016: 9), in connected, multiscale networks (Cilliers \& Cilliers, 2016: 20). The increasing focus on water is fitting, not only considering water as a critical issue in both global wetting and warming and the ecosystem services provided by water bodies and systems, but also considering that the useful life of water infrastructure is commonly measured in hundreds of years, requiring that contemporary infrastructure investments meet the requirements and challenges of the twenty-second century (Muller, 2007: 100). In ecosystem-based adaptation approaches, ecological structures, their functions, and services are utilised to increase the capacity of areas and inhabitants to reduce risks as a result of climatic extremes and variability (Timmermans, Woestemburg, Annema, Jonkhof, Shllaku \& Yano, 2015; Wamsler et al., 2016: 3). Ecosystem-based adaptations thus rely on a multitude of ecosystem management activities made up of a range of blue-green infrastructure components, including parks and gardens, street trees, permeable surfaces, urban wetlands, watercourses, ponds, lakes and green roofs that are directly or indirectly intended to reduce climate risk (Wamsler et al., 2016: 3).

\subsection{Urban adaptation strategies}

A range of urban strategies have been devised to address the consequences of climate change and related extreme weather conditions. These strategies are increasingly being incorporated 
into spatial planning strategies with specific spatial design principles incorporated to make the city 'climate proof'. The strategies devised for Belgium, The Netherlands and Australia were selected based on the comprehensive nature of the proposals they contain, that address several climatic challenges within the scope of urban development, based mainly on ecosystem-based approaches.

\subsubsection{Belgium: Six spatial strategies proposed by the Flemish government}

In being aware of climate change impacts and the need to address them, the Flemish government devised six spatial strategies based on the report 'Climate adaptation and qualitative and quantitative guidelines for the spatial development of regions' (Koen Couderé, Van Gassen, Nagels, Dhondt \& Debuysere, 2015). Table 1 captures these six spatial strategies.

These six spatial strategies focus mainly on approaches to adaptation that work with the natural environment and introduce more greenery to improve thermal performance. The following subsection captures proposals for Belgium's neighbour, The Netherlands.

\subsubsection{The Netherlands: Design principles from a multi- institute collaboration}

In The Netherlands, several

knowledge institutes jointly published the report 'Designing green and blue infrastructure to support healthy urban living' in 2016 (Gehrels et al. 2016: 11-109), describing multiple green and blue measures at city and street level to make a city healthier for its inhabitants. The report steps beyond climate issues and describes many specific measures for urban climate adaptation. It shows how green and blue measures at city and street level can be used to tackle heat stress; decrease noise pollution; encourage physical activity; regulate water quality; decrease feelings of stress; increase social interaction, and improve air quality. The report pays much attention to a proper methodology and specific design principles (see Table 2).

Table 1: $\quad$ Six spatial strategies for climate adaptation from Belgium

\begin{tabular}{|l|l|l|}
\hline \multicolumn{1}{|c|}{ Spatial strategy } & \multicolumn{1}{|c|}{ Explanation } \\
\hline $\begin{array}{l}\text { Softening hardened } \\
\text { surfaces }\end{array}$ & $\begin{array}{l}\text { Develop permeable surfaces or } \\
\text { replace with greens. }\end{array}$ & $\begin{array}{l}\text { Reduce building footprints; greening semi-private gardens and parks; introducing infiltrating } \\
\text { infrastructure; develop new green spaces; preserve existing soft spaces; limit hardening of } \\
\text { infrastructure. }\end{array}$ \\
\hline Afforestation & Plant trees and shrubs. & $\begin{array}{l}\text { Introduce green elements along existing infrastructure networks; increase greenery in parks; } \\
\text { increase greenery in private green spaces; introduce urban forests; develop green squares and } \\
\text { large green open spaces. }\end{array}$ \\
\hline Ventilation & $\begin{array}{l}\text { Take advantage of existing } \\
\text { dominant wind directions to } \\
\text { optimise cooling and improve air } \\
\text { quality. }\end{array}$ & $\begin{array}{l}\text { Channel wind and breezes; remove blockages; develop areas where cooling winds may } \\
\text { originate. }\end{array}$ \\
\hline Control heat retention & Wall and roofing adaptations. & $\begin{array}{l}\text { Introduce more reflective hard surfaces; green roofs; use building materials with reflective or } \\
\text { absorption qualities; green facades; create more shadows. }\end{array}$ \\
\hline Provide space for water & $\begin{array}{l}\text { Allow areas for waterbodies and } \\
\text { watercourses. }\end{array}$ & $\begin{array}{l}\text { Space for rivers; capture rainwater; increase accessibility to water; introduce water misting in } \\
\text { public spaces; combine the cooling effects of water and greenery; develop water buffer and } \\
\text { infiltration spaces. }\end{array}$ \\
\hline Shielding & $\begin{array}{l}\text { Provide protection against hard } \\
\text { wind or excessive solar radiation. }\end{array}$ & $\begin{array}{l}\text { Shield public spaces; develop dikes and other shielding structures; develop on, and with water, } \\
\text { for example, floating buildings and/or buildings on pillars. }\end{array}$ \\
\hline
\end{tabular}

Source: Own construction based on Vlaanderen (2015)

Table 2: Design principles for climate adaptation from The Netherlands

\begin{tabular}{|c|c|c|}
\hline Design principles & Explanation & Examples \\
\hline Water regulation & Reduce storm-water runoff. & $\begin{array}{l}\text { Canopy interception and evaporation; infiltration; root water uptake and transpiration; green } \\
\text { roofs. }\end{array}$ \\
\hline $\begin{array}{l}\text { Air-temperature } \\
\text { regulation }\end{array}$ & $\begin{array}{l}\text { Regulate the urban heat island effect and } \\
\text { heat stress }\end{array}$ & $\begin{array}{l}\text { Maintain and increase percentage of trees; add trees with large crowns in streets, parks } \\
\text { and squares; consider vegetation maintenance; apply infiltration to guarantee sufficient } \\
\text { soil-moisture content. }\end{array}$ \\
\hline Air-quality regulation & $\begin{array}{l}\text { Increase the deposition of pollutants; } \\
\text { alter wind flow; emit biogenic volatile } \\
\text { compounds and pollen. }\end{array}$ & $\begin{array}{l}\text { Consider residence time of air and possible blocking of air exchange by trees and } \\
\text { structures; consider fitting green infrastructure for specific context and conditions; structural } \\
\text { maintenance of green infrastructure to regulate size and density. }\end{array}$ \\
\hline Noise reduction & Address noise pollution. & $\begin{array}{l}\text { Locate vegetation buffers close to source of noise; favour evergreen species; mix trees and } \\
\text { shrubs to densify buffers; select plants tolerant to air pollution and de-icing; natural buffers } \\
\text { are less effective than planned buffers; consider topography and existing landforms. }\end{array}$ \\
\hline Mental health & $\begin{array}{l}\text { Capitalise on potential for improved mental } \\
\text { health. Good-quality urban waters facilitate } \\
\text { leisure activities that relieve stress and } \\
\text { contribute to quality of life. }\end{array}$ & $\begin{array}{l}\text { Maximise visual contact with green elements; offer high-quality, immersive and restorative } \\
\text { experiences in green space; limit algae growth and prevent floating layers of duckweed or } \\
\text { algae; limit resuspension. }\end{array}$ \\
\hline $\begin{array}{l}\text { Impact of green } \\
\text { infrastructure on } \\
\text { social interaction and } \\
\text { physical exercise }\end{array}$ & $\begin{array}{l}\text { Promote and accommodate social } \\
\text { interaction and physical exercise. }\end{array}$ & $\begin{array}{l}\text { Green spaces should accommodate diverse attributes and facilities; accessible green } \\
\text { spaces located in proximity (range of } 2.5 \mathrm{~km} \text { ) of where people live, linked with affordable } \\
\text { public transport; green infrastructure designed around motives of green infrastructure users. }\end{array}$ \\
\hline $\begin{array}{l}\text { Urban waters and } \\
\text { medical health }\end{array}$ & $\begin{array}{l}\text { Water quality in terms of pollution and } \\
\text { exposure to pathogens, toxic chemicals } \\
\text { and algal toxins. }\end{array}$ & $\begin{array}{l}\text { Keep water clean by minimising sewer overflows, surface runoff and creating a flow from } \\
\text { better to worse; decrease water flow rate to separate sediment; purify by maintaining water } \\
\text { temperature and introduce certain plants. }\end{array}$ \\
\hline $\begin{array}{l}\text { Impact of blue } \\
\text { infrastructure on } \\
\text { healthy living }\end{array}$ & $\begin{array}{l}\text { Stimulate healthy living by providing } \\
\text { opportunities for activities. }\end{array}$ & $\begin{array}{l}\text { Connect waterways to other urban and rural systems via cycle and walkways along water } \\
\text { systems. }\end{array}$ \\
\hline
\end{tabular}

Source: Own construction based on Gehrels et al. 2016: 25-56 
The first two urban adaptation strategy examples provide generic principles and tools that can be used for climate-adaptive urban design. It is important to note the emphasis on water and blue infrastructure in both the Belgian and the Dutch strategies. The last example, a strategic design approach, is taken from Australia, as a country with experience of severe climates and innovative policy and design responses. Subsection 2.3.3 focuses on the Water-Sensitive Urban Design approach.

\subsubsection{Australia: Water-Sensitive Urban Design}

Australia pioneered the concept of 'the Water-Sensitive City' (Wong, 2006: 1), introducing the paradigm of Water-Sensitive Urban Design (WSUD). The WSUD approach is a visionary approach to integrate sustainable urban planning and water management that aims to minimise the hydrological impacts of urban development on the surrounding environment. Figure 3 provides a schematic representation of the natural water balance, as the natural state; urban water balance, showing the impacts of urban development on features such as evapotranspiration, runoff and infiltration, and the WSUD approach, in adapting the urban water cycle for a Water-Sensitive City.

Wong \& Brown (2009: 676) describe three pillars to integrate urban development and water management in pursuit of the Water-Sensitive City, through WSUD, reiterated in Van Hattum et al. (2016: 9) under descriptions of the Water Smart City. The three pillars are captured in Table 3.

The design principles and considerations on climate-adapted development and WSUD placespecific emphasis on placeappropriate adaptation. The following section examines the case study of Essenvelt, Middelburg in The Netherlands and provides some adaptation recommendations based on the literature and three strategies summarised above.

\section{METHODS}

The case study of Essenvelt, Middelburg, is examined following a desktop analysis in keeping with the qualitative research tradition. The case study was identified, motivated and further informed by ongoing research on temperature variations and climatic conditions in Middelburg (Caljouw, 2017: online), supplemented by core publications, scholarly articles and online resources sourced from electronic databases and academic search engines.

\subsection{Case study: Essenvelt, Middleburg}

Middelburg was selected as a fitting case study to apply ecosystem-based adaptations utilising some of the principles of blue-green planning previously explored and presents application possibilities in a new district to be developed in the future in Essenvelt (Figure 4). The city of Middelburg is located in southwestern Netherlands, in the province of Zeeland's central peninsula.

Essenvelt is an undeveloped parcel of land located on Middelburg's southern border towards the harbour city of Vlissingen, located $7.5 \mathrm{~km}$ from Middelburg (Figure 4). Considering the potential for urban expansion in the Essenvelt district, this section offers customised design recommendations to address climate change at both district and building levels. Main challenges addressed in this regard include night-time heat and issues related to a gradual increase in the salinity of deeper groundwater under the peninsula.

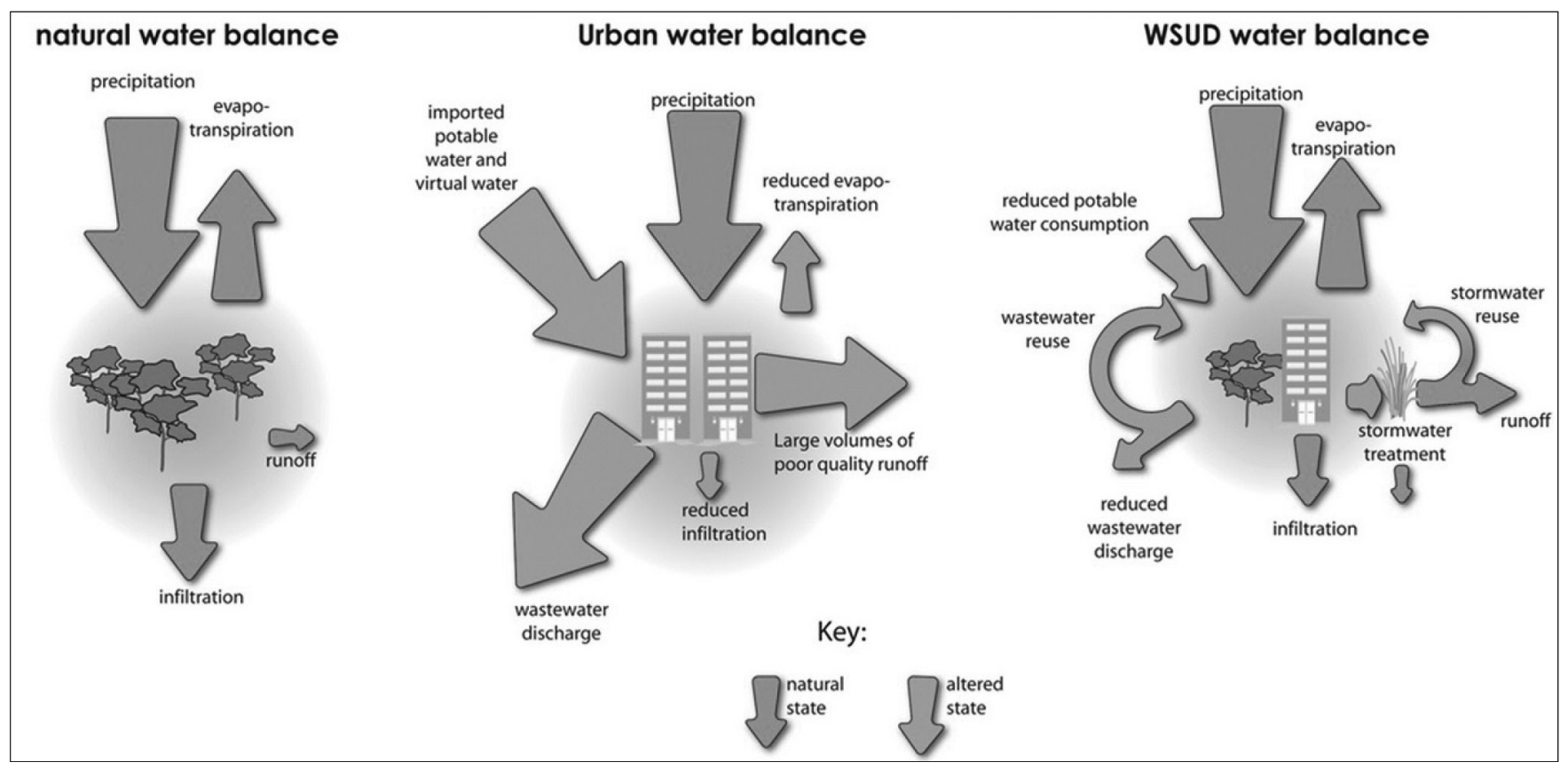

Figure 3: The urban water management cycle

Source: Hoban \& Wong, 2006 
Table 3: Integrating urban development and water management based on three pillars for WSUD

\begin{tabular}{|c|c|c|}
\hline Pillar of WSUD & Explanation & Example \\
\hline $\begin{array}{l}\text { Cities as water-supply } \\
\text { catchments }\end{array}$ & $\begin{array}{l}\text { Cities need to draw on a range of water resources delivered via a diverse and } \\
\text { integrated network of centralised and decentralised infrastructure at different scales. } \\
\text { Thus, establishing a portfolio of water sources to draw on that may demand the least } \\
\text { environmental, social and economic costs. }\end{array}$ & $\begin{array}{l}\text { Groundwater, urban storm water, rainwater, } \\
\text { recycled waste water and desalinated water. }\end{array}$ \\
\hline $\begin{array}{l}\text { Cities providing } \\
\text { ecosystem services } \\
\text { and increasing } \\
\text { liveability }\end{array}$ & $\begin{array}{l}\text { The integration of urban landscape design and green infrastructure/nature-based } \\
\text { solutions that may mitigate the urban heat island effect, contribute to local food } \\
\text { production, support biodiversity, and reduce greenhouse gas emissions by promoting } \\
\text { biking and outdoor recreation. } \\
\text { With nature-based solutions for water management, it is possible to: } \\
\text { - Protect and enhance natural water systems in urban developments; } \\
\text { - Integrate storm water treatment into the landscape by incorporating multiple use } \\
\text { corridors that maximise visual and recreational amenity; } \\
\text { - Protect water quality draining from urban development; } \\
\text { - Reduce runoff and peak flows from urban developments by introducing local detention } \\
\text { measures and minimising impervious areas; } \\
\text { - Integrate solutions for flood reduction, drought and heat mitigation; } \\
\text { - Add value while minimising drainage infrastructure development costs. }\end{array}$ & $\begin{array}{l}\text { Storm water treatment technologies such } \\
\text { as constructed wetlands and bio-retention } \\
\text { systems (rain gardens) and the rehabilitation } \\
\text { of degraded urban waterways. }\end{array}$ \\
\hline $\begin{array}{l}\text { Cities comprising } \\
\text { water-smart } \\
\text { communities and } \\
\text { institutions }\end{array}$ & $\begin{array}{l}\text { Sociopolitical capital is needed for sustainability and water-sensitive decision-making from } \\
\text { communities, developers and institutions that have the capacity to get involved in the } \\
\text { 'urban water problem' and develop water-sensitive strategies. }\end{array}$ & $\begin{array}{l}\text { Mandatory water-quality targets; using } \\
\text { public art to communicate objectives; } \\
\text { profiling community attitudes and receptivity } \\
\text { to water reuse and pollution prevention } \\
\text { activities; community participatory action } \\
\text { models, including scenario workshops and } \\
\text { community-based deliberative forums. }\end{array}$ \\
\hline
\end{tabular}

Source: Own construction adapted from Wong \& Brown, 2009: 676-679

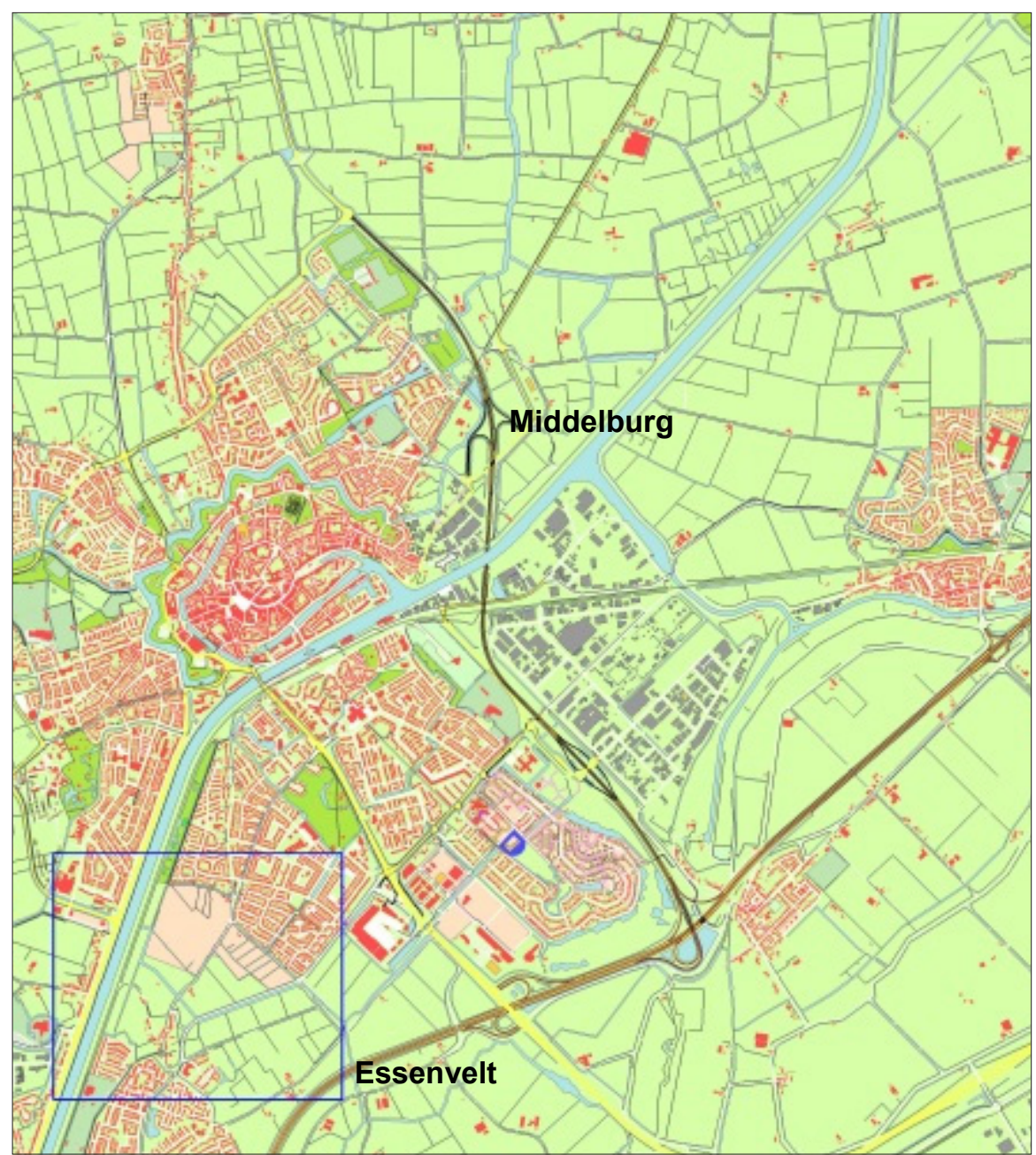

Figure 4: Middelburg and Essenvelt
It has long been assumed that heat stress is not a problem in this area because of the proximity of the sea. Whereas it is commonly held that proximity to large water bodies, such as the ocean, will provide a cooling effect over land, such impacts are not guaranteed. This is illustrated in Figure 5, which shows the minimum temperature measured on 24 August 2016, during a relatively hot late summer period in The Netherlands. Figure 5A shows that the area near Vlissingen presents the highest minimum temperature in the country, despite its location in proximity to the sea in the western part of the province of Zeeland. This illustrates that, even in coastal areas, under certain meteorological circumstances, high night-time temperatures can be observed, with known impacts on human health and productivity (Rovers et al., 2015: 3), as introduced in section 2.1. In Western Europe, minimum temperatures higher than $20^{\circ} \mathrm{C}$ are considered critical (Fischer \& Schär, 2010: 399). It is expected that the number of hot nights with a temperature above $20^{\circ} \mathrm{C}$ in an average summer will increase to over 20 by 2050 (Klimaat, 2017).

Source: Opentopo, 2017 


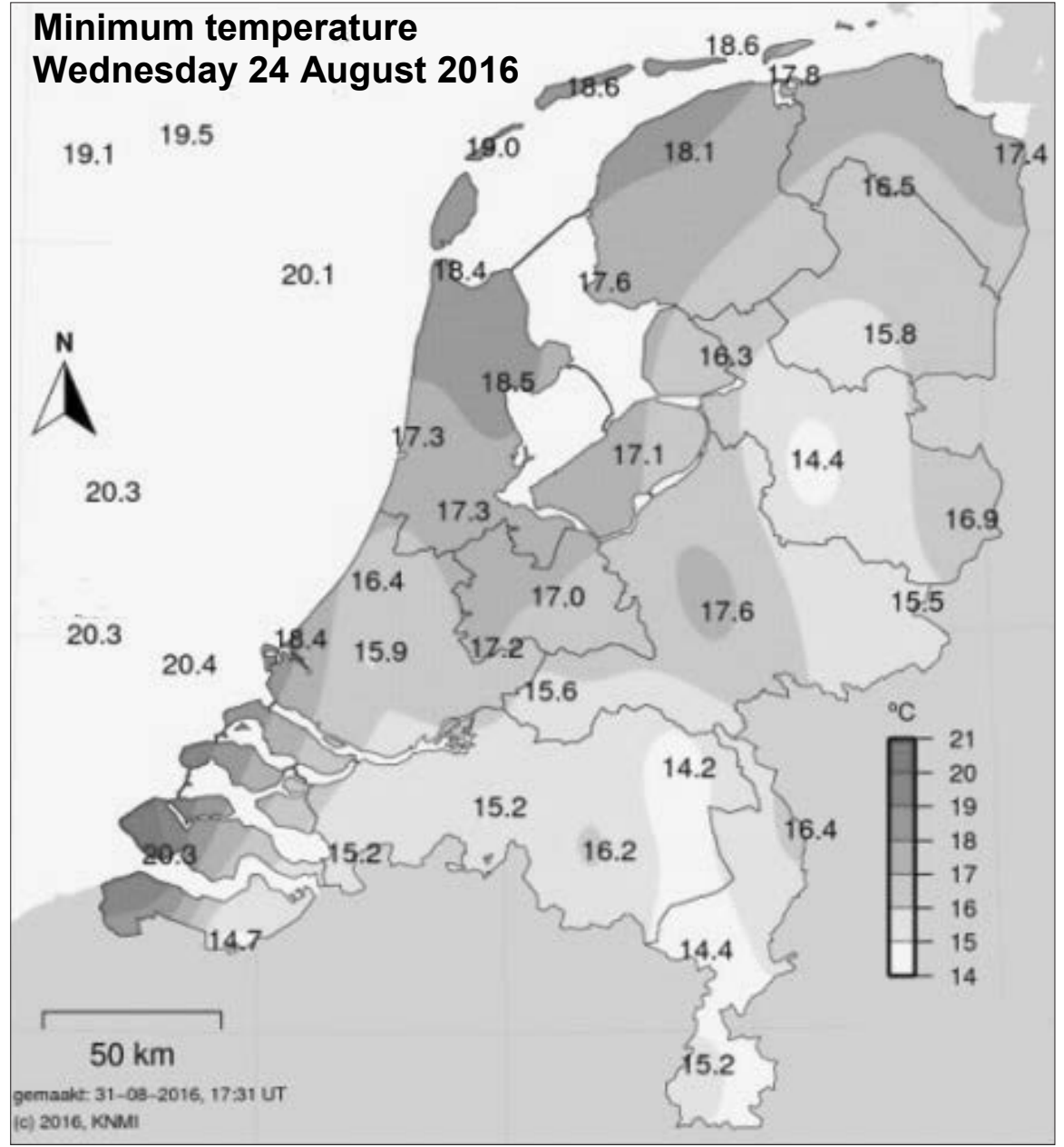

Figure 5: Temperature map of The Netherlands

Source: $\quad$ Royal Netherlands Meteorological Institute (KNMI), www.knmi.nl

Further research on the causes of western Zeeland's relatively high night-time temperatures is currently underway. It suffices to mention that the phenomenon illustrated above conforms to observations and model calculations indicating that water may contribute to heating instead of cooling, in particular during late summer nights (Steeneveld et al., 2014: 92; Jacobs La Rivière \& Goosen, 2014: 136; Gunawardena, Wells \& Kershaw, 2017: 1040). By autumn, the seawater tends to display relatively high temperatures. As a result, and given the delayed cooling effect of the sea and Westerschelde estuary, nocturnal cooling above water might be less than expected and less in comparison to cooling above land. Adaptation recommendations should be provided accordingly. recommendation focuses on windbased adaptations.

\subsubsection{Wind: Ensuring natural cooling}

Wind may improve thermal comfort in the city during hot periods (Van Hove, Jacobs, Heusinkveld, Elbers, Van Driel \& Holtslag, 2015: 102) in the summer and during heatwaves when both day- and night-time temperatures may be elevated. As such, it seems pertinent that newly built structures be planned not to block cooling winds in the summer. It follows that natural ventilation be prioritised with consideration for local wind climate, wind direction and varied regional and coastal impacts. In the Essenvelt case, consideration should be given to areas where cooling winds may originate, for example over certain water bodies, with air flow channelled accordingly. Furthermore, design approaches should facilitate air exchange with consideration for the blockages potentially presented by trees and structures to allow warm air to escape throughout the day. In the same vein, it is also important to guard against the potential nuisance effects of wind in hot periods and diminished thermal comfort in other periods when temperatures may already be very low. Wind is considered in both the Belgian and the Dutch strategies provided. The second set of recommendations examines building-design adaptations.

\subsubsection{Building design: Designing and constructing with the climate in mind}

In placing building structures, layout designs should consider shielding public spaces and private residences from excessive solar radiation. Reducing building footprints in exchange for greater green area cover will reduce the impacts of the urban heat island effect. Building smaller or higher structures could be of benefit. Measures should be taken in designing and fitting buildings to prevent daytime heating and encourage cooling at night, reducing the need for artificially cooled air. As examples, south-facing windows may be screened in summer when the sun is high, whereas windows orientated to the east or west should be avoided. 


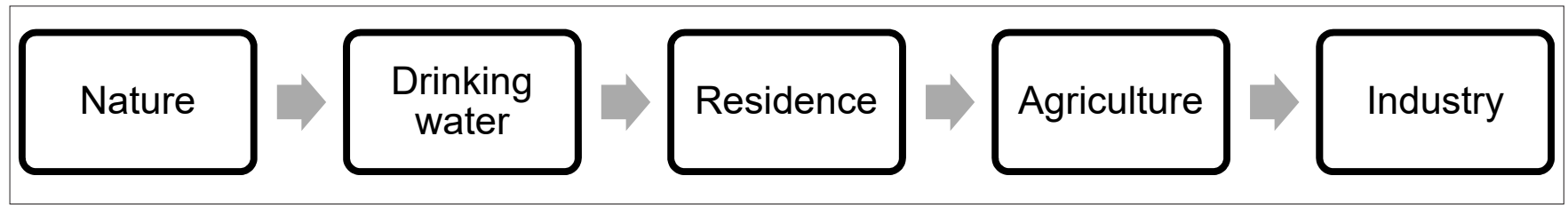

Figure 6: Waterflow from clean to black

Source: $\quad$ Author's own construction, 2017

In relation to the aforementioned use of wind, shutter systems may be introduced to allow cooling at day and night and to block direct exposure to sunlight. In pursuit of more shadows, awnings and roof overhangs may be introduced to provide shade during the day. It will also be important to utilise reflective or absorbent hard surfaces and building materials. Adaptation strategies already developed for The Netherlands (see Table 2) reference building design especially. The following recommendations focus on the use of vegetation, echoing the green infrastructure approach.

\subsubsection{Vegetation: Greener infrastructure for cooler environments}

Owing to the nature of ecosystembased adaptation strategies, greening the urban environment is considered a key adaptation strategy for Essenvelt. Linking with the aforementioned focus on building design and building materials, green roofs and fronts should be introduced as standard practice, with ventilation and insulation capacities designed in accordance with needs. The greenfield nature of future development in Essenvelt provides the opportunity to develop ample new green space and promote the cultivation of private green spaces. Introducing minimum guidelines on greening public and private spaces such as public open spaces and gardens may prove fruitful in regulating temperatures. Indigenous trees should be introduced to regulate climate in public spaces, streets, homes and industries in a manner of afforestation. Hardened infrastructure networks should be avoided in favour of softer, green alternatives. Green infrastructure should be designed in a network that incorporates and connects with blue

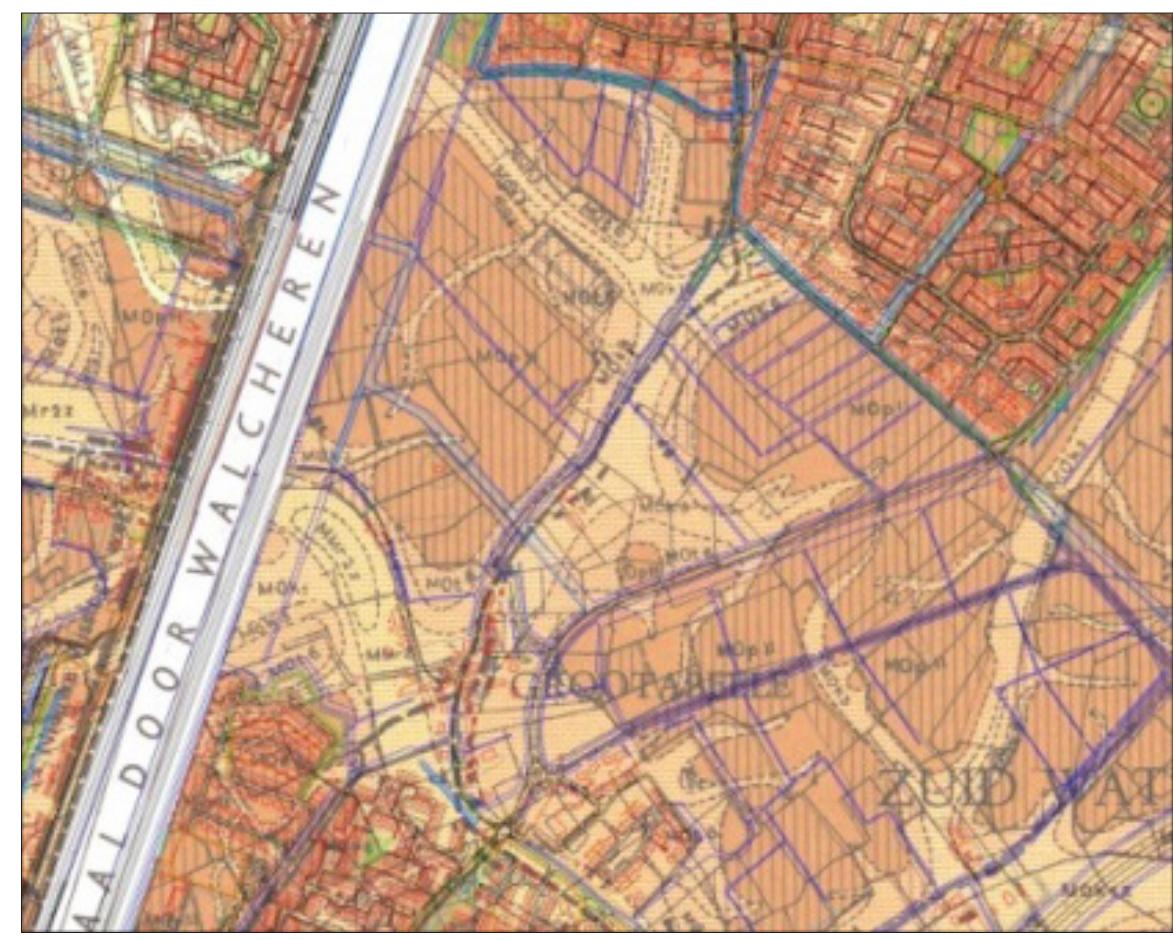

Figure 7: Essenvelt soil map showing lower lying clay soil (dark colours) and sandy cove ridges (light colours)

Source: $\quad$ WUR, 2017

infrastructure. Blue infrastructure adaptation recommendations are provided accordingly.

\subsubsection{Water: Considering blue infrastructure recommendations and WSUD}

The role of water surfaces in improving ventilation should not be discounted (Van Hove et al., 2015: 102). New development in Essenvelt should draw on any nearby surface water to provide additional cooling, the temperature of which may be regulated using shadows to ensure that the water remains cooler than the air, linking with the focus on shadows, cool waterbodies and wind provided in subsection 3.2.1. It is further recommended that a blue infrastructure network be introduced that works with the natural environment, incorporates existing provisions, and provides space for water. Middelburg is situated on the coast in the Rhine-MeuseScheldt delta and its water system is traditionally a polder system. In fulfilling the need for a new water system for Essenvelt, existing polders could be used as the basis of the new network. The system should be arranged to ensure that surface water flows from clean to black to maintain water quality, following strategies in Table 2 (Figure 6). Added to this, mandatory water-quality targets could be set and upheld, as per the WSUD approach, in an attempt to keep water clean and of high quality. Furthermore, the soil map (Figure 7) shows that the area contains both lower lying clay soil and sandy cove ridges. The ridges offer the opportunity to store collected fresh (rain) water, ensuring sufficient supply of drinking water in periods of drought 
and increasing the area's watercatchment capacity. In recognition of a gradual increase in the salinity of deeper groundwater under the peninsula, where groundwater is extracted for use, desalination should be considered to improve water quality and usability. Water should further be used as a central design element in public spaces, developing waterbodies and features and actively regulating temperature through water misting, for example. In accordance with the WSUD approach, community members should also be included in participatory workshops to educate residents on water use and pollution prevention, in order to entrench WSUD within the community. Such workshops should make residents aware of the causes of increased night-time temperatures and provide them with information on coping with the phenomenon.

\section{CONCLUSION}

This article provided a review of key considerations with regard to climate adaptation as an increasingly important component of urban planning strategies in the modern age. Research shows that climate adaptation strategies should consider a range of diverse impacts. For example, increased night-time temperatures alongside an increased likelihood of precipitation, flooding and other extreme weather events. Proactive adaptation strategies are required to meet the challenge of climate change head on and advance the sustainability and resilience of human settlements. In pursuing the climate-proof city, urban planners and managers, as part of a multidisciplinary approach, may draw on a range of adaptation initiatives already established across the globe, of which the key principles are represented in the Belgian, Dutch and Australian examples provided.

Such ecosystem-based and watersensitive approaches hold the benefit of targeting key concerns (e.g., high night-time temperatures as in the Middelburg and Essenvelt case), whilst simultaneously addressing multiple other climate-related issues. Such strategies hold substantial value to improve urban quality of life and citizen health and to protect urban infrastructure and assets from damage and stress. The task no longer lies in merely recognising the impacts of climate change or mitigating effects, but in drawing on the growing literature on adaptation strategies and learning from practical examples of implementation. Whilst retrofitting urban areas to be greener and more adaptive is an essential part of establishing climate-proof cities, new urban extensions and greenfield developments present the opportunity to do things right from the start. In this regard, Essenvelt, Middelburg, may present excellent adaptation possibilities that may draw on established 'best practice' and the Dutch tradition of planning with water. The opportunity should be seized to pilot-adaptation strategies developed on the back of public participation initiatives and publicprivate partnerships that deliver community-driven outcomes to tackle climate change directly. The task lies in ultimately incorporating adaptation strategies as part of routine development practice and not as an exception to the norm.

\section{REFERENCES}

BIOTOPE-CITY. 2017. Biotope-city journal. [Online]. Available at: <http:// www.biotope-city.net.> [Accessed: 20 September 2017].

BIZIKOVA, L., CRAWFORD, E., NIJNIIK M. \& SWART, R. 2014. Climate change adaptation planning in agriculture: Processes, experiences and lessons learned from early adapters. Mitigation and Adaptation Strategies for Global Change, 19(4), pp. 411-430. https://doi. org/10.1007/s11027-012-9440-0

BULKELEY, H. \& TUTS, R. 2013. Understanding urban vulnerability, adaptation and resilience in the context of climate change. Local Environment, 18(6), pp. 646-662, http://dx.doi.org/10. 1080/13549839.2013.788479.

CALJOUW, L. 2017. Impactproject ontwikkelinginstrument hittestress voor steden en dorpen in het landelijk gebied. [Online]. Available at: <https://ruimtelijkeadaptatie. nl/voorbeelden/@168824/ hittestress-zeeland/>.[Accessed: 20 September 2017].
CBD (CONVENTION ON BIOLOGICAL DIVERSITY). 2009. Connecting biodiversity and climate change mitigation and adaptation: report of the Second Ad Hoc Technical Expert Group on Biodiversity and Climate Change. Technical Series No. 41. CBD, Montreal, Quebec, Canada.

CILLIERS, E.J. \& CILLIERS, S. 2016.

Planning for green infrastructure: Options for South African cities. Johannesburg: South African Cities Network.

CILLIERS, E.J., DIEMONT, E., STOBBELAAR, D.J. \& TIMMERMANS, W. 2011. Enhancing sustainable development by means of the workbench method. Environment and Planning B: Planning and Design, 38(4), pp. 579-584. https://doi. org/10.1068/b37111

CLAES, K., VANDENBUSSCHE, L., VERSELE, A., KLEIN, R. \& VERBIST, B. 2012. Sustainable urban planning and construction in the South. KLIMOS working paper, pp. 1-42.

COLDING J. 2011. The role of ecosystem services in contemporary urban planning. In: Niemelä, J., Breuste, J.H., Elmqvist, T., Guntenspergen, G., James, P., Mclntyre, N. (Eds). Urban ecology: Patterns, processes and applications. New York: Oxford University Press, pp. 228-237. https://doi.org/10.1093/acprof: oso/9780199563562.003.0028

DAANEN, H.A., JONKHOFF, P., $B O S C H, H . \&$ TEN BROEKE, $\mathrm{H}$. 2013. The effect of global warming and urban heat islands on mortality, morbidity and productivity in The Netherlands. In: Cotter, J.D., Lucas, S.J.E. \& Mündel, T. (Eds.). Proceedings of the $15^{\text {th }}$ International Conference on Environmental Ergonomics, 11-15 February 2013, Queenstown, New Zealand. University of Otago: International Society of Environmental Ergonomics, pp. 16-19.

EEA (EUROPEAN ENVIRONMENTAL AGENCY). 2012. Urban adaptation to climate change in Europe Challenges and opportunities for cities together with supportive national and European policies. EEA Report No 2/2012, pp. 5-143. ISSN 1725-9177.

EEA (EUROPEAN ENVIRONMENTAL AGENCY). 2017. Climate change, impacts and vulnerability in Europe 2016. An indicator-based report. EEA Report No 1/2017, pp. 8-334. ISSN 1977-8449. 
FANG, G. 2015. Prediction and analysis of urban heat island effect in Dangshan by remote sensing. International Journal on Smart Sensing and Intelligent Systems, 8(4), pp. 2195-2211.

FISCHER, E.M. \& SCHÄR, C. 2010. Consistent geographical patterns of changes in high-impact European heatwaves. Nature Geoscience, vol. 3, pp. 398-403. https://doi.org/10.1038/ ngeo866

FUSSEL, H.M. 2008. Assessing adaptation to the health risks of climate change: What guidance can existing frameworks provide? International Journal of Environmental Health Research, 18(1), pp. 37-63. https://doi. org/10.1080/09603120701358416

GEHRELS, H., VAN DER MEULEN, S., SCHASFOORT, F., BOSCH, P., BROLSMA, R., VAN DINTHER, D., GEERLING, G., GOOSSENS, M., JACOBS, C., DE JONG, M., KOK, S., MASSOP, H., OSTÉ, L., PÉREZ-SOBA, M., ROVERS, V., SMIT, A., VERWEIJ, P., DE VRIES, B. \& WEIJERS, E. 2016. Designing green and blue infrastructure to support healthy urban living. Research report, TO2 federatie, The Netherlands: Energy research Centre of the Netherlands (ECN).

GIBBS, M. 2015. Guiding principles for infrastructure climate change risk and adaptation studies. Civil Engineering and Environmental Systems, 32(3), pp.206-215. https://doi.org/10.1080/102 86608.2015.1025385

GUDMUNDSSON, L. \&

SENEVIRATNE, S.I. 2016.

Anthropogenic climate change affects meteorological drought risk in Europe. Environmental Research Letters, 11(4), pp. 1-9. https://doi. org/10.1088/1748-9326/11/4/044005

GUNAWARDENA, K.R., WELLS, M.J. \& KERSHAW, T. 2017. Utilising green and blue space to mitigate urban heat island intensity. Science of the Total Environment, 584-585, pp. 1040-1055. https://doi.org/10.1016/j. scitotenv.2017.01.158

HOBAN, A. \& WONG, T. 2006. Water sensitive urban design for resilience to climate change. In: Proceedings of the $1^{\text {st }}$ Australian National Hydropolis Conference, Perth, Western Australia, 8-11 October 2006.

HU, X., HALL, J.W., SHI, P. \& LIM, W.H. 2016. The spatial exposure of the Chinese infrastructure system to flooding and drought hazards.
Natural Hazards, 80(2), pp. 10831118, DOI 10.1007/s11069-0152012-3. https://doi.org/10.1007/ s11069-015-2012-3

HUYNEN, M.M.T.E., MAARTENS, P., SCHRAM, D., WEIJENBERG, M.P. \& KUNST, A.E. 2001. The impact of heatwaves and cold spells on mortality rates in the Dutch population. Environ Health Perspect, 109(5), pp. 463-470. https://doi.org/10.1289/ehp.01109463

IPCC (INTERGOVERNMENTAL PANEL ON CLIMATE CHANGE). 2014. Climate Change 2014: Synthesis Report. Contribution of Working Groups I, II and III to the Fifth Assessment Report of the Intergovernmental Panel on Climate Change [Core Writing Team, R.K. Pachauri and L.A. Meyer (eds). Geneva, Switzerland: IPCC.

JACOBS, C.M.J., LA RIVIĖRE, I. \& GOOSEN, H. 2014. Cool water tool. Landschap: Tijdschrift voor Landschapsecologie en Milieukunde, 31(3), pp. 132-138.

KENNEDY, D., STOCKER, L. \& BURKE, G. 2010. Australian local government action on climate change adaptation: Some critical reflections to assist decision-making. Local Environment, 15(9-10), pp. 805-816. https://doi.org/10.1080/13549839.2010 .514602

KLIMAAT. 2017. Klimaateffectatlas. [Online]. Available at: <www. klimaateffectatlas.

nl.> [Accessed: 2 April 2017].

KLOK, E.J. \& KLUCK, J. 2017.

Reasons to adapt to urban heat (in The Netherlands). Urban Climate, 2017 (In press - forthcoming).

KOEN COUDERÉ, K., VAN GASSEN, B., NAGELS, M., DHONDT, A. \& DEBUYSERE, F. 2015. Klimaatadaptatie en kwalitatieve en kwantitatieve richtlijnen voor de ruimtelijke inrichting van gebieden. Study conducted for Ruimte Vlaanderen.

KUNDZEWICZ, Z.W. 2015. Climate change track in river floods in Europe. In: Cudennec, C., Eicker, A., Pilon, P., Stoffel, M., Viglione, A. \& Xu, Z. (Eds). Proceedings of IAHS-IACS-IAG Joint Symposium JH1, $26^{\text {th }}$ General Assembly of the International Union of Geodesy and Geophysics, 22 June-2 July 2015, Prague, Czech Republic, vol. 369, pp. 189-194, 201. https://doi. org/10.5194/piahs-369-189-2015
LAUKKONEN, J., BLANCO, K.P., LENHART, J., KEINER, M., CAVRIC, B. \& KINUTHIA-NJENGA, C. 2009. Combining climate change adaptation and mitigation measures at the local level. Habitat International, 33(2009), pp. 287-292. https://doi.org/10.1016/j. habitatint.2008.10.003

MILOJEVIC, I., ARMSTRONG, B.G., GASPARRINI, A., BOHNENSTENGEL, S.I., BARRATT, B. \& WILKINSON, P. 2016. Methods to estimate acclimatization to urban heat island effects on heat- and cold-related mortality. Environmental Health Perspectives, 14(7), pp. 1016-1022. https://doi.org/10.1289/ehp.1510109

MULLER, M. 2007. Adapting to climate change: Water management for urban resilience. Environment \& Urbanization, 19(1), pp. 99-113. https:// doi.org/10.1177/0956247807076726

NOORDHOF ATLASPRODUCTIES/ KNMI 2011. De Bosatlas van het klimaat. Groningen: Noordhof Uitgevers.

OKE, T.R. 1981. Canyon geometry and the nocturnal urban heat island: Comparison of scale model and field observations. Journal of Climatology, 1(3), pp: 237-254. doi:10.1002/ joc.3370010304. https://doi. org/10.1002/joc.3370010304

OPENTOPO. 2017. Opentopo. [Online]. Available at: <https://data.nlextract.nl/ opentopo/400pixkm/jpg/2017-R09/40048W.jpg> [Accessed: 3 April 2017].

ROBINE, J., CHEUNG, S., LEROY, S., VANOYEN, H., GRIFFITHS, C., MICHEL, J. \& HERRMANN, F. 2008. Death toll exceeded 70,000 in Europe during the summer of 2003. Comptes Rendus Biologies, 331(2), pp. 171-178. https://doi.org/10.1016/j. crvi.2007.12.001

ROVERS, V., BOSCH, P. \& ALBERS, R. (Eds). 2015. Climate-proof cities 2010-2014 - Final report. Knowledge for Climate, Report 129/2014, Climate-proof cities consortium. www. knowledgeforclimate.nl.

SAMANIEGO, L., THOBER, S., KUMAR, R., RAKOVEC, O., WOOD, E., SHEFFIELD, J., PAN, M., WANDERS, N. \& PRUDHOMME, C. 2017. Drought and heatwaves in Europe: Historical reconstruction and future projections. Geophysical Research Abstracts, 19, p. 2. 
SMITH, K.R., WOODWARD, A., CAMPBELL-LENDRUM, D., CHADEE, D.D., HONDA, Y., LIU, Q., OLWOCH, J.M., REVICH, B. \& SAUERBORN, R. 2014. Human health: Impacts, adaptation, and co-benefits. In: Field, C.B., Barros, V.R., Dokken, D.J., Mach, K.J., Mastrandrea, M.D., Bilir, T.E., Chatterjee, M., Ebi, K.L., Estrada, Y.O., Genova, R.C., Girma, B., Kissel, E.S., Levy, A.N., MacCracken, S., Mastrandrea, P.R. \& White, L.L. (Eds), Climate change 2014: Impacts, adaptation, and vulnerability. Part A: Global and sectoral aspects. Contribution of Working Group II to the Fifth Assessment Report of the Intergovernmental Panel on Climate Change. Cambridge: Cambridge University Press, pp. 709-754.

STEENEVELD, G.J., KOOPMANS, S., HEUSINKVELD, B.G., VAN HOVE, L.W.A. \& HOLTSLAG, A.A.M. 2011. Quantifying urban heat island effects and human comfort for cities of variable size and urban morphology in The Netherlands. Journal of Geophysical Research: Atmospheres, 116(D20129). doi: 10.1029/2011JD015988. https:// doi.org/10.1029/2011JD015988

STEENEVELD, G.J., KOOPMANS, S., HEUSINKVELD, B.G. \& THEEUWES, N.E. 2014. Refreshing the role of open water surfaces on mitigating the maximum urban heat island effect. Landscape Urban Plan, 121, pp. 92-96. https://doi.org/10.1016/j. landurbplan.2013.09.001

TIMMERMANS, W., WOESTENBURG, M., ANNEMA, H., JONKHOF, J., SHLLAKU, M. \& YANO, S. 2015. The rooted city, European capitals and their connection to the landscape. Wageningen, The Netherlands: Blauwdruk.

TZOULAS, K., KORPELA, K., VENN, S., YLI-PELKONEN, V., KAZMIERCZAK, A., NIEMELÄ, J. \& JAMES, P. 2007. Promoting ecosystem and human health in urban areas using green infrastructure: A literature review. Landscape and Urban Planning, 81(3), pp. 167-178. https://doi.org/10.1016/j. landurbplan.2007.02.001

VAN DEN HURK, B.J.J.M., SIEGMUND, P. \& KLEIN TANK, A. (Eds). 2014. KNMl'14: Climate change scenarios for the $21^{\text {st }}$ century - A Netherlands perspective. Scientific Report WR2014-01, KNMI, De Bilt, The Netherlands.
VAN HATTUM, T., BLAUW, M., BERGEN JANSEN, M. \& DE BRUIN, K. 2016. Towards water-smart cities climate adaptation is a huge opportunity to improve the quality of life in cities. Report no. 2787 of Wageningen Environmental Research (Alterra), pp. 1-60.

VAN HOVE, L.W.A., JACOBS, C.M.J., HEUSINKVELD, B.G., ELBERS, J.A., VAN DRIEL B. \& HOLTSLAG, A.A.M. 2015. Temporal and spatial variability of urban heat island and thermal comfort within the Rotterdam agglomeration. Building and Environment, 83, pp. 91-103. https://doi.org/10.1016/j. buildenv.2014.08.029

VAN HOVE, L.W.A., STEENEVELD, G.-J., JACOBS, C.M.J., TER MAAT, H.W., HEUSINKVELD, B.G., ELBERS, J.A., MOORS, E.J. \& HOLTSLAG, A.A.M. 2010. Modelling and observing urban climate in The Netherlands. Report KvR 020/10, National Research programme Climate Changes Spatial Planning Foundation. [Online]. Available at: <http://www. klimaatvoorruimte.nl/onderzoekthemas/ communicatie/COM29> [Accessed: 22July 2017].

VLAANDEREN. 2015. Ruimtelijke strategieën. [Online]. Available at: $<$ http://www.klimaatenruimte.be/ ruimtelijke-strategie $\% \mathrm{C} 3 \% \mathrm{ABn}>$ [Accessed: 2 April 2017].

WAMSLER, C., NIVEN, L., BEERY, T.H., BRAMRYD, T., EKELUND, N., JÖNSSON, K.I, ADELINA OSMANI, A., PALO, T. \& STÅLHAMMAR, S. 2016.

Operationalizing ecosystem-based adaptation: Harnessing ecosystem services to buffer communities against climate change. Ecology and Society, 21(1), article 31. [Online]. Available at: http://dx.doi.org/10.5751/ ES-08266-210131 [Accessed: 1 August 2017]. https://doi.org/10.5751/ ES-08266-210131

WONG, T.H.F. 2006. Water-sensitive urban design, the journey thus far. Australasian Journal of Water Resources, 10(3), pp. 213-222.

WONG, T.H. \& BROWN, R.R. 2009. The water-sensitive city: Principles for practice. Water Science and Technology, 60(3), pp. 673-682. doi:10.2166/wst.2009.436. https://doi. org/10.2166/wst.2009.436

WUR. 2017. Wagenigen University Soil Archive, Department of Soil Quality, Wageningen University, Wageningen, The Netherlands.
ZIERVOGEL, G., MIDGLEY, G., MYERS, J., NEW, M., TAYLOR, A., VAN GARDEREN, E.A., HAMANN, R., WARBURTON, M. \& STUART-HILL, S. 2014. Climate change impacts and adaptation in South Africa. WIREs Climate Change, 5(5), pp. 605-620. doi: 10.1002/wcc.295. https://doi. org/10.1002/wcc.295 